\title{
Rifkin's foot in the door
}

Washington

AT a hearing this month, the US Court of Appeals gave some preliminary indications of how it will rule on the motion by the National Institutes of Health (NIH) and the University of California to lift a lower court ban on field trials of recombinant organisms. Although a decision from the three-judge panel is not expected for several months, the judges last week repeatedly interrupted attorneys for $\mathrm{NIH}$, the university and Jeremy Rifkin - the antigenetic-engineering activist who obtained the lower-court injunction with questions that suggested how they would vote.

The injunction was based on a finding by US District Court Judge John Sirica last spring that NIH must conduct a formal "environmental assessment" before approving the experiment proposed by $\mathrm{Dr}$ Steven Lindow of the University of California, in which genetically-altered bacteria were to be sprayed on potato plants to provide protection against frost. Even though the proposal was discussed at two open meetings of NIH's Recombinant DNA Advisory Committee (RAC) and published in the Federal Register for public comment, Sirica found that the law requires a formal document; he also concluded that RAC and NIH failed to consider possible environmental consequences of the experiment such as the effect of the bacteria on nearby plants and insects.

The preliminary injunction granted by Sirica also blocks NIH from approving any other field trials of recombinant organisms until NIH prepare an environmental impact statement on the full programme of field trials. NIH say that such a statement would take a year to prepare, and would be of little value because of the widely disparate nature of the field trials that are likely to be proposed. NIH have agreed, however, to prepare the much briefer environmental assessments on each field trial that is proposed. The University of California is continuing to challenge both the programmatic environmental impact statement requirement and the need for an environmental assessment on the Lindow experiment.

At the hearing, Judge George MacKinnon, who is generally considered to be the most conservative of the three, appeared to accept the government's argument that the RAC guidelines require the equivalent of an environmental assessment on each proposal submitted, whether or not there is a formal document with that name on it. And he several times sharply challenged Rifkin's attorney on the need for a programmatic environmental impact statement (EIS), pointing to precedents that established such a requirement only for programmes with a clearly cumulative effect.
Judge Abner Mikva, who is regarded as a liberal, suggested that if NIH were required to prepare such a statement, it would of necessity be vague and hypothetical; he told Rifkin's attorney that if his goal was closer scrutiny of the environmental consequences of field trials, "you might be better off without a programmatic EIS - frequently an agency will issue a broad EIS and then refer to that to cover all their sins".

If what appears likely happens - that the court allows RAC to proceed with approval on a case-by-case basis, but requiring an individual environmental assessment for each - Rifkin will still have gained the foot in the door that he is after. By establishing that RAC's review proce-

dures are subject to the National Environmental Policy Act - the law that requires environmental assessments and environmental impact statements - Rifkin will open the way for routine court challenges every time RAC approves a field trial; he will presumably argue that the environmental assessment in each case was not adequate or that a full environmental impact statement is required. Rifkin has said in several interviews that there should be a "moratorium" on field trials until a "framework" for assessing all the risks is established, a condition which he maintains is not possible with current knowledge. And he has also said that any environmental assessment should be done on a "worst-case" basis.

Meanwhile, RAC's staff is proceeding with preparation of an environmental assessment of the Lindow experiment.

Stephen Budiansky

\section{European Parliament Commission's budget rejected}

THE massive vote by the European Parliament last week to reject the whole 1985 budget of the European Commission could mean trouble for the European fifthgeneration computer project, Esprit, and for other scientific projects planned to grow or start afresh next year.

Esprit, for example, which links individual European computer and electronic companies in joint pre-competitive research projects, cost 45 million European accounting units (ECU) in 1984 (some $£ 25$ million). The programme was due to more than double to 100 million ECU in 1985. But under the rules governing the operation of the European Community without an official budget, spending must go on forward by "provisional twelfths" - each month the Commission will be able to spend no more than a twelfth of total spending in the previous year, in each individual line of the 1984 budget.

Of eight major programmes tabled for discussion at this week's meeting of research ministers (see Nature 15 November, p. 187), five are likely to receive no cash at all in 1985 until the battle with the European Parliament is settled. The non-nuclear energy programme, for example, may come to a total halt - its second programme finished 18 months ago, and since it had no official budget line in 1984, under the rules it cannot be funded in any fashion next year.

European parliamentarians, who have largely rejected the budget in a play for greater influence over the radical restructuring of the Community now under discussion among European heads of state, were last week attempting to play down the damage their decision has done to research. But the damage can be limited: some new programmes, it is pointed out in Brussels, must go through lengthy exercises of setting up expert committees and putting out calls for tender. If the council of ministers meeting this week approves some of the programmes in principle, it may be possible to get through a large part of 1985 without spending an ECU, while nevertheless making some useful preparations to spend when the purses are filled again.

Robert Walgate

\section{Hunting heads}

THE Department of Education and Science is taking the un-British step of asking a head-hunting firm to suggest candidates for posts as the head of two research councils due to become vacant next year. The posts concerned are those as chairman of the Science and Engineering Research Council (which Professor John Kingman will leave at the end of August 1985) and chairman of the Natural Environment Research Council (which Mr Hugh Fish will vacate at the end of September 1985).

This unusual step appears to have been forced on the government by the dearth of acceptable names reaching it from the usual nominating bodies that constitute the old-boy network. The head-hunters, John Stork and Partners, have been retained only as advisers, and will be expected to provide Sir Keith Joseph, the Secretary of State for Education and Science, with a list of names from which to make a choice.

Part of the difficulty attending this is that the salary offered, that of an undersecretary in the civil service (now just over

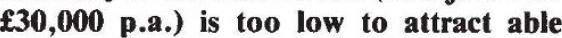
people from industry and hardly enough to compensate senior academic scientists for the invidious responsibility of administering policies (or budgets) that must lose them friends. The usual compensation of a knighthood is not always a sufficient recompense, and cannot be traded in for heat and light. 